\title{
Otoendoscopy aids diagnosis of a rare ear canal tumour
}

\author{
Caroline Rachael Anderson, ${ }^{1,2}$ Fiona McClenaghan, ${ }^{1}$ Ezra Nigar, ${ }^{1}$ Surojit Pal ${ }^{1}$
}

${ }^{1}$ Ear, Nose and Throat Surgery, Northwick Park Hospital, Harrow, UK

${ }^{2}$ EvidENT, the Ear Institute, University College London, London, UK

\section{Correspondence to}

Miss Caroline Rachael Anderson, c.anderson@doctors.org.uk

The 154th Semon Club

Accepted 12 December 2018

Check for updates

(c) BMJ Publishing Group Limited 2019. No commercial re-use. See rights and permissions. Published by BMJ.

To cite: Anderson $C R$, McClenaghan F, Nigar $E_{\text {, }}$ et al. BMJ Case Rep

2019:12:e228417.

doi:10.1136/bcr-2018

228417

\section{DESCRIPTION}

A 31-year-old woman presented with a 1-year history of mild conductive hearing loss and sensation of blockage in her left ear. She had no otalgia, tinnitus or vertigo. Otoendoscopic examination showed a smooth, skin coloured mass with a cystic-glandular appearance arising from and covering the medial two-thirds of the anterior wall of the left ear canal (figure 1A).

CT petrous bones assessed the extent of the lesion with regard to the underlying bone and middle ear. It showed an $8 \mathrm{~mm}$ ovoid soft-tissue lesion abutting the tympanic membrane and with focal thinning of the adjacent floor and anterior wall of the bony canal (figure 1B)

Wide local excision was undertaken following multidisciplinary team discussion, and histology was consistent with a ceruminous adenoma, a rare, benign tumour arising from the ceruminous glands (figure 1C,D). She made an excellent recovery with no signs of recurrence at 6 months.

Ceruminous adenoma can cause almost any otological symptoms, but most commonly presents as sensation of a mass or conductive hearing loss. ${ }^{1}$

The obstruction of the ear canal predisposes to concurrent otitis externa, which combined with the rarity of masses in the ear canal and the nondescript radiological appearance, makes it a diagnostic challenge. There have been no case reports with

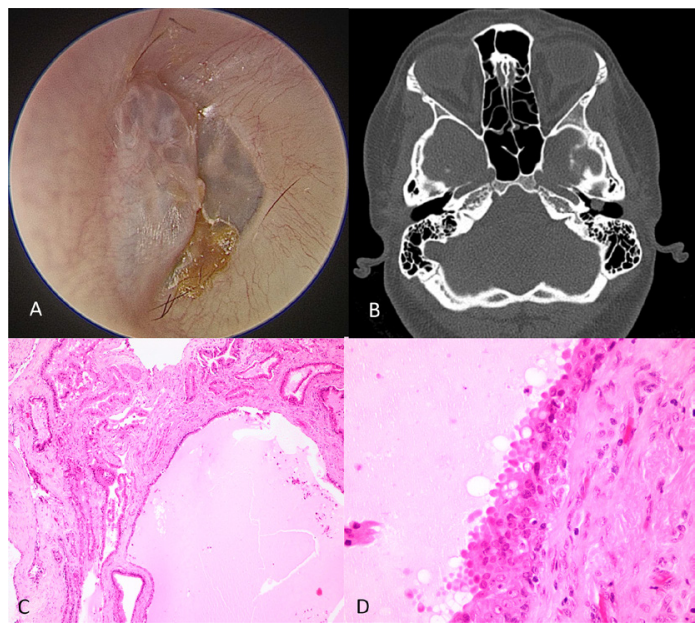

Figure 1 (A) An otoendoscopic image showing tumour arising from the anterior canal wall. The cystic glandular structure is appreciable. (B) CT scan of the petrous bones showing a soft - tissue lesion within the left external auditory canal. (C) Lesion overview: cystic glandular spaces are lined by bland cuboidal and oncocytic epithelium (x40). (D) Lining epithelium shows apical snouts (apocrine secretions) (x100).

\section{Patient's perspective}

At first I was unsure if I wanted to go ahead with surgery as I was scared of the worst case scenario, but I did know I wanted it dealt with. It was the best decision I took, as my surgery and recovery was quick and concise and I healed well.

clinical images of ceruminous adenoma, and its clinical features have been variably described in the literature, with cases describing a 'pink, smooth non tender mass" ; a 'reddish, rounder, tender soft mass with discharging yellow fluid' 3 and a 'mass...covered by skin'. They are usually located on the posterior ear canal wall, although this case is an exception to this rule. ${ }^{5}$ Otoendoscopy allows a clearer and closer view than traditional otomicroscopy, allowing identification of features suggestive of the diagnosis. Its disadvantages lie in loss of depth information due to the two-dimensional nature of the images, and fogging of the scope obstructing the view. Both of these can be overcome in the clinic setting by combining otoendoscopy with otomicroscopy.

Histologically, ceruminous adenoma has been well described, tending to be unencapsulated, demonstrating glands and small cysts, lined by proliferation of inner ceruminous cells. Cells commonly contain golden-yellow-brown pigment cytoplasmic granules. ${ }^{1}$

Treatment is by surgical excision, for symptomatic relief and to prevent infection, and there are excellent cure rates from complete resection. ${ }^{1}$

\section{Learning points}

- Otoendoscopy is a painless, clinic-based investigation, which allows excellent visualisation of abnormalities within the ear canal and aids diagnosis of external auditory canal tumours.

- Tumours of the ear canal are a rare but important cause of common symptoms, and require surgical intervention to prevent complications.

Contributors CA drafted the article and acquired images and permissions. FM planned and revised the article. EN drafted the figure legend and acquired histopathological images. SP planned and revised the article, and managed the patient.

Funding The authors have not declared a specific grant for this research from any funding agency in the public, commercial or not-for-profit sectors

Competing interests None declared.

Patient consent Obtained. 
Images in...

Provenance and peer review Not commissioned; externally peer reviewed.

\section{REFERENCES}

1 Thompson LD, Nelson BL, Barnes EL. Ceruminous adenomas: a clinicopathologic study of 41 cases with a review of the literature. Am J Surg Pathol 2004;28:308-18.

2 Shen WQ, Cheng KJ, Bao YY, et al. Expression of Glut-1, HIF-1 $\alpha$, PI3K and p-Akt in a case of ceruminous adenoma. Head Neck Oncol 2012;4:18.
3 Psillas G, Krommydas A, Karayannopoulou G, et al. Ceruminous adenoma of the external auditory canal: a case report with imaging and pathologic findings. Case Rep Med 2015;2015:1-3.

4 Uz U, Tan A, Celik O. Ceruminous adenoma mimicking otitis externa. SAGE Open Med Case Rep. 2018;6:2050313X18777147. Published 2018.

5 Thompson LD. Update from the 4th edition of the World Health Organization classification of head and neck tumours: tumours of the ear. Head Neck Pathol 2017;11:78-87.

Copyright 2018 BMJ Publishing Group. All rights reserved. For permission to reuse any of this content visit https://www.bmj.com/company/products-services/rights-and-licensing/permissions/

BMJ Case Report Fellows may re-use this article for personal use and teaching without any further permission.

Become a Fellow of BMJ Case Reports today and you can:

- Submit as many cases as you like

- Enjoy fast sympathetic peer review and rapid publication of accepted articles

- Access all the published articles

- Re-use any of the published material for personal use and teaching without further permission

For information on Institutional Fellowships contact consortiasales@bmjgroup.com

Visit casereports.bmj.com for more articles like this and to become a Fellow 